\title{
Structure, Evolution and Hot Spots of Cooperation Innovation Knowledge Network
}

\section{-Bibliometric Analysis from SCI (2000-2014)}

\author{
Xinyue Zhang, Wei Song \\ The School of Public Affairs, University of Science and Technology of China, Hefei, China \\ Email: zxyxk@ustc.edu.cn
}

Received 28 March 2015; accepted 15 April 2015; published 22 April 2015

Copyright (C) 2015 by authors and Scientific Research Publishing Inc.

This work is licensed under the Creative Commons Attribution International License (CC BY).

http://creativecommons.org/licenses/by/4.0/

\section{(c) (i) Open Access}

\section{Abstract}

Based on the statistics analysis of cooperation innovation articles, the paper analyses the distributing characteristics of cooperation innovation research papers. The distribution, structure and evolution of cooperation innovation research are studied through the social network and co-word method, combined with the information visualization technology. This study is based on the papers in the SSCI database during 2000-2014. The analysis and statistics of papers reveal distribution characteristics of the subject, time, institutions, countries and areas. The statistics shows that the research perspective of cooperation innovation from business and economics. The time distribution presents that research of cooperation innovation attracts enormous attention and the research achievement is increasing. From the distribution of organizations, countries and areas, North America and Europe countries maintain the leading position in this research field. But institutions and universities of China and other Asian countries or areas are witnessed their outstanding achievements in cooperation innovation research. Combining the co-word network analysis method, the paper studies the structure and content of cooperation innovation knowledge network in five stages and makes the net spectrum, visually showing the hot spots at various periods. The top highly cited papers in all five stages are reviewed simultaneously; their research hot spots and evolution process are concluded. The study shows 11 subjects including strategic alliances, social networks, R\&D cooperation, R\&D, technology transfer, alliances, knowledge management, social capital, entrepreneurship, trust, biotechnology are always the central issues in last 15 years. The focus of research is from the relationship between alliance and technology innovation to networking and knowledge innovation and then to open innovation.

\section{Keywords}

Cooperation Innovation, Co-Word Networking, Visualization, Bibliometric, 


\section{Knowledge Structure}

\section{Introduction}

\subsection{The Research Significance of Cooperation Innovation}

The cooperation is usual way by corporations, research institutions, university and public sectors to implement innovation. The cooperation promotes the knowledge flow and source complementary. The traditional way in which those organizations make research and development independently becomes less important. The latest innovation pattern enlightens that enterprises should extend their innovation range and applies the external knowledge sources [1], which can reduce the challenge to enterprises like short products life cycle, fast update of products and increasing cost for research and development [2].

The enterprises develop and innovate in the development and research increasingly depending on the external sources [3]. They can get the necessary, various sources to create value by cooperation [4]-[6]. When enterprises lack the important sources or their environment is uncertain, they would attempt to cooperate with other enterprises [7] [8]. Das et al. (2002) [9] think the ability to learn how to cooperation make the administration and coordination of enterprises more effective. Enterprises can improve their ability of new cooperation and administration of further cooperation. Zollo et al. (2002) [10] think the diversified cooperation can accumulate the know-how and prompt the enterprises adaptability and flexibility to different cooperation in the future.

The relationship between cooperation and innovation is an important content of researchers. Shan et al. (1994) [11] discover the cooperation and innovation output are correlated in biotechnology industries. Nooteboom (1999) [12] believes that learning the cooperation skills, the enterprises can get more understanding and trust among cooperation parties, reduce the cost of coordination and business and increase the accumulated and fundamental innovation performance. Ahuja (2000) [13] proves by the example of international chemical industry that profit of cooperation outweigh the structure holes and suggests the enterprise can increase the innovation performance by cooperation. The cooperation can be made with other enterprise or with academic institution or customers. The cooperation with diversified cooperators can enhance the effect of development and research alliance on enterprises' innovation performance [14] [15]. Belderbos (2006) [16] thinks the cooperation between enterprise and customers is purposed to get brainstorm and reduce the risks. In order to ensure the fast expansion in the market, the new products are tried out by customer and improved by their feedback. The cooperation with customers is intended to lower the cost of key business and improve the quality, seek for process innovation. The cooperation with competitors aims to share the cost of research and development, to gain the synergy by sharing sources or to make regulations and industry standards. The cooperation with academic or research institutions is to look after the fundamental breakthrough in product innovation, which may open a brand-new or segment market. Hagedoorn et al. (2000) [17] concludes ten effects of cooperation on innovation: decrease the transaction cost of research and development; extend the effective range of innovation activity; make networks to increase the efficiency, strengthen the coordination and boost the market interest; gain the external and complementary source and ability to take advantage of existing resource and develop sustainable, competitive advantage; prompt organizing to learn, to internalize the core-competitiveness; create the new investment opportunity in innovation of high opportunity and risk. Internalize the knowledge output while increase the information sharing and intensify the specificity of research achievements; decrease the R\&D cost; share the risk. The scholars believe the organizations must cooperate with each other instead of they are willing to do it because the technology and market that promise the success are controlled by others or one element of value chain is professional [18] [19]. Rosenkopf et al. (2001) [20] develop the search ability cross boundary of organization and technology. He finds that the non-cross-boundary search process can have negative effect on the subsequent technology innovation and points out that the effect of exploratory research can be enormous only if the search cross the border of organizations and technology. Powel et al. (1996) [21] study the cooperation among biotechnology enterprises and comment the contribution of cooperation to study and performance. They show enterprise involved into beneficial network can gain more innovation performance. The evolution economics research suggests that if an enterprise can open to external environment, its innovation ability can be enhanced. Evolution economist emphasizes that the functions of research are to help organizations find diverse sources and 
allow them to innovate the combination of new technology and knowledge [22]. The diversity provides the optional technology approaches for enterprises [23]. The searching strategy is largely influenced by the availability of opportunity and search activities of other enterprises [24]. The experiences from previous cooperative projects are considered be possible to improve the R\&D ones in progress [25]; for example, Dyer et al. (1998) [26] and Barajas et al. (2010) [27] discuss that the cooperation experience can lead to development of relationship capital and effective cooperation practice, which can promote the knowledge transforming and reduce the costs of transaction and coordination in an R\&D cooperation [28].

\subsection{The New Concept of Cooperation Innovation}

Cooperation innovation is a process to develop series of new products and technologies by cooperating with other organizations. It includes the opportunity recognition, originality creation and technology application and diffusion. Cooperation innovation is an organization form to make technological innovation. It is a cooperative agreement and arrangement by different organizations for common target. It is a necessary organization tool to gain the sources that are difficult to transfer in uncertain market [29]. The involvement of other organization at certain stage during the innovation process can also be deemed as cooperation innovation [30].

Numerous new concepts relevant to cooperation innovation occur in many research papers at home and abroad. Chesbrough (2003) [1] points out the concept of open-ended innovation. He thinks the enterprises can gain necessary innovation resources through external cooperation. Teece (1992) [31] states that one of basic characters in new economic time is continue convergence of technologies, only by which the enterprises can gain more innovation opportunities and get edge at market. As cooperation innovation as their topics, those research achievements all emphasize that the organizations can improve the innovation performance through external cooperation.

In recent years, many new research hot spots around innovation like open-ended innovation, coordination innovation, and common innovation are produced. Different as in definitions, all those concepts are found by deep research the cooperation action and process for innovation targets in essence. Therefore, the scholars keep keen interest in research for innovation by cooperation. In reality, no matter whether the organizations are profit or non-profit, they all confront the complex and uncertain competition environment. It is especially difficult to make innovation individually and independently. They need cooperate with each other to reduce the risks in innovation practice for better performance.

The paper combines the opinions of scholars and extents the content of cooperation innovation. It deems that the exchange, study and transmission of knowledge between or among organizations by source sharing or advantage complementing are also cooperation innovations.

\subsection{The Contribution of This Paper}

The author focuses on the cooperation innovation and keeps enhancing and deepening its concept. By reviewing and classifying the relevant research of cooperation innovation, the author finds those researches focus on one special theory or analyze the research from single perspective and do not clearly define the cooperation innovation completely.

Furthermore, the traditional way to review papers by choosing the important parts or summarizing the papers of high-frequency citation may cause careless omission of some latest papers of high research significance because of the hysteresis. The method of bibliometrics can overcome the weakness because it combines the mathematics and statistic methods to quantificationally analyzes the papers. Integrating the mathematics, statistics and philology, the diachronous methods of bibliometrics is a comprehensive intellectual system to realize the classification and research of papers.

Additionally, there are some articles that applies the diachronous methods of bibliometrics to analyze the innovation papers, but those articles are based on the domestic data base or just study one particular branch of cooperation innovation as some papers only abstract the technology coalition or open-end innovation, or they jest pay attention the alternation during short term. They lack the systematic conclusion and induction for cooperation innovation and the research for evolution of it, especially the research of hot spots of cooperation innovation form the economic and administrative aspects.

Above all, based on the diachronous methods of bibliometrics, social network and web of science database, the paper analyzes the cooperation innovation achievements in recent 15 years. The key words of those are ana- 
lyzed by co-word network. Through the research for characters and evolution of cooperation innovation network and phased analysis, and combining the quantitative and qualitative analysis, the author explores the network structure and evolution characters of cooperation innovation. The paper also visually shows us the research structure, hot spots and development tendency of international cooperation innovation. Its conclusion lays a foundation and shows the direction for further research of innovation by economic and administrative fields. Specific studies are as follows:

- Integrate and develop the concept and content of cooperation innovation.

- Taking the papers with subject of cooperation innovation during 15 years from 2000 to 2014 as its study object, the author makes a bibliometrics analysis of distribution of subjects and magazines about cooperation innovation and finds main study tendency in commercial and economic field. The database is from SCI, and the research duration meet the requirement for evolution analysis.

- Analyze the characteristics of knowledge network of cooperation innovation by technology methods of complex network.

- Apply the visualization and make co-word network spectrum at various stage, visually explain the research hot spots and their evolution process of cooperation innovation at every stage.

- Combining the qualitative and quantitative analysis method instead of only quantitative analysis, the paper analyses the high cited cooperation innovation papers.

\section{Data Collection and Research Method}

\subsection{Data Collection}

SCI is a citation database published by American Science Information Research Institution in 1961. It is an internationally recognized and key searching tool for scientific statistics and comments. The paper chooses two scientific citation databases: SCI-Expanded, SSCI to index. The steps are as follows.

- Confirmation of Subject

The paper defines the cooperation innovation. The index is TS $=$ INNOVATION AND TS $=($ COOPERATION OR COLLABORATION OR SYNERGY OR COORDINATION), i.e. all the articles with subjects like cooperation innovation, collaborative innovation and coordination innovation are all within research scope.

- Confirmation of Time

The author makes a pre-index and finds the articles of cooperation innovation before 2000 is not many, so the author make the duration from 2000 to end of 2014 for latest hot research spots of cooperation innovation.

- Confirmation of Research Field

SCI sets two research areas: one is by Research Areas and another is Web of Science Categories. By the former, 111 research areas about corporation innovation have been found. The top 10 and their distribution are shown in Table 1. The cooperation areas are found mainly in Commercial Economy, Engineering Science and Public Administration. Corporation innovation research is closely focused in commercial economic activities, industry application and public administration.

Table 1. Distribution of research areas in cooperation innovation.

\begin{tabular}{clll}
\hline S/N & Research Area & Total & 2771 \\
1 & Business Economics & 885 \\
2 & Engineering & 623 \\
3 & Public Administration & 457 \\
4 & Environmental Sciences Ecology & 314 \\
5 & Operations Research Management Science & 392 \\
7 & Computer Science & \\
8 & Information Science Library Science & 261 \\
10 & Geography & 218 \\
\end{tabular}


If indexed by Web of Science Categories, 100 categories on cooperation innovation are totally found. Top 25 categories are shown in Table 2. Among them, $37.3 \%$ is about management, $18.6 \%$ about business and $11.1 \%$ about economics with other categories like engineering industry and information science library science, etc. cooperation innovation research is obviously found an interdisciplinary and multidisciplinary one and mainly from the aspects of management, business and economics.

This paper indexes by Research Areas and finds the corporation innovation achievements in business economics are $51.3 \%$ of total achievements. There are three reasons why author focuses on the business economics area. One is that focusing on single area makes the conclusion more pertinent and applicable. Second is the large percentage of achievement in the business economics fully expresses the scientific research tendency and the quantity can meet the requirements of research in network structure, character and evolution process. Final reason is that although the articles chose by author are in business economics, the area covers many disciplines including management, economics and even the engineering and their interdisciplinary areas.

By indexing and by sorting out the overlapped articles, author chooses 2771 articles as subjects. The article information is abstracted and analyzed by softwares like Bibexcel, Ucinet and Pajek.

\subsection{Research Method}

SNA (Social Network Analysis) is an important branch of up-to-date scientific research method. It has developed a normal research formula with special concept system and measuring tool. It analyzes the social structures and properties of social relationship among social units (individuals, groups or elements) by a series of nodes and the node links.

At present, SNA is widely applied for bibliometrics method, especially for discovering the important hidden relationship behind individual intellectual unit like abstract, key works and authors etc. By the theory of SNA, co-citation networks of high-frequent key words in articles are analyzed. The key words are the nodes of wordgroup networks. Co-citation relationship is presented by unidirectional link, of which the thickness shows how close their relationship. In all, as a necessary complement of cluster analysis, the SNA can effectively avoid the unreasonable defects caused by format conversion of co-word matrix in cluster analysis and clearly and objectively show the original relationship of research objects.

\section{Bibliometirc Information}

\subsection{Time Distribution}

The research data sources from articles on cooperation innovation from 2000 to 2014. The relevant research on innovation management has been rapidly developed in last 15 years. Table 3 shows the annual quantity of articles and their increasing tendency. From 51 in 2000 to 374 in 2014, the increasing figure proves the cooperation innovation is a research hot spot in business economics.

Table 2. Distribution of web of science categories in cooperation innovation.

\begin{tabular}{ccc}
\hline S/N & Web of Science Categories & Total \\
\hline 1 & Management & 2004 \\
2 & Business & 1012 \\
3 & Economics & 617 \\
4 & Planning Development & 537 \\
5 & Engineering Industrial & 490 \\
6 & Operations Research Management Science & 414 \\
7 & Environmental Studies & 351 \\
8 & Information Science Library Science & 332 \\
10 & Geography & 261 \\
\hline
\end{tabular}


Table 3. Total of published articles on cooperation innovation (2000-2014).

\begin{tabular}{cccccccccc}
\hline Year & 2000 & 2001 & 2002 & 2003 & 2004 & 2005 & 2006 & 2007 \\
\hline Total & 51 & 53 & 66 & 89 & 95 & 109 & 132 & 152 \\
Year & 2008 & 2009 & 2010 & 2011 & 2012 & 2013 & 2014 & SUM \\
Total & 184 & 223 & 252 & 303 & 322 & 366 & 374 & 2771 \\
\hline
\end{tabular}

\subsection{Distribution of Journals}

By statistics, 2771 articles are published on 413 Journals. Authors make a statistics on top 15 Journals. As shown in Table 4, Research Policy, Technovation, International Journal of Technology Management are top three. Research Policy can be said a journal of considerable referential importance in innovation research. It belongs to management academic journal, which commits to analyzing, understanding and effectively dealing with articles about challenges by innovation, technology, R\&D and science in economics, policy, management, organization and environment etc. It covers the activities relevant to intellectual creation, transmission and acquisition and their application in new or updated products, procedures or services. Technovation includes concepts about new technology products or procedures and all aspects in technical innovation process. The research subjects cover technology tendency, innovation breakthrough, new product development, availability of foreign capitals, displacement of existing products, management of venture capital, innovation management of medium-sized and large organizations, organization structure to improve innovation, venture strategy based on new science and technology, individual innovator and technology transfer in developing countries, etc.

\subsection{Distribution of Countries and Areas}

According to statistics, there are 62 countries and 1 area make research of cooperation innovation. Figure 1 show the top 15 countries or area with most published articles. Among them, America, England, Swaziland, Germany and Italy are top five with their published articles quantities 798,344,254,247 and 205 respectively. It presents that the research in North American and Europe countries are more than other countries.

In Asia, China ranks eighth with 134 published articles. It proves that China gain certain achievement on cooperation innovation research, which should be credited to continue economic development. However, comparing with European and North American countries, China has lots to be desired.

\subsection{Distribution of Research Institution}

The statistics result of corporation innovation research institutions as shown in Table 5, it shows that the research institution with the most published articles is University of Manchester, whose published articles are 60. The second is University of California System with its published articles up to 57, and University of London next with 50. In the top 15 research institutions, 5 from the Netherlands, 4 from USA, 3 from the United Kingdom, the rest from Italy, Finland and Italy respectively, the research institutions of Europe and the United States in the field of cooperation innovation occupy a leading position.

\section{Cooperation Innovation Research Subjects Spectrum}

The paper first abstracts the key words in 2771 articles by Bibexcel software and finds that some early-published articles are without key words, but they have actually up to 9 key words only in one article. There are totally 9880 key words in 2771 articles, but the average noted key words only 3.56.

Looking through all key words, the author omits the key words without important meanings like symbols and merges some key words like singular with plural, abbreviation with its original form like capabilities with Capability, Research and Development with R\&D, Small and medium-sized enterprises with SMES. The author leaves other types of key words as their originals because: First, the word must be well understood in its specific context. The merge of words that are seemingly similar without fully understanding their meaning may loss important information; Second, even the same word has different meaning in different context; third, a small number of key words cannot influence result.

\subsection{The Nature of Knowledge Network}

From 2000 to 2014, the nodes of co-word network for innovation management research are respectively 150 , 
Table 4. Journal distribution table (top 15 journals).

\begin{tabular}{clc}
\hline S/N & Journal & Total \\
\hline 1 & Research Policy & 244 \\
2 & Technovation & 124 \\
3 & International Journal of Technology Management & 110 \\
4 & Journal of Product Innovation Management & 100 \\
5 & Technology Analysis Strategic Management & 72 \\
6 & R\&D Management & 69 \\
7 & Industrial Marketing Management & 67 \\
8 & Technological Forecasting and Social Change & 63 \\
9 & Industry and Innovation & 53 \\
10 & Organization Science & 53 \\
11 & Journal of Technology Transfer & 52 \\
12 & Innovation Management Policy Practice & 43 \\
13 & Journal of Business Research & 43
\end{tabular}

\section{Table 5. The top 15 institutions of authors.}

\begin{tabular}{cllc}
\hline S/N & Institution & Total & Proportion \\
\hline 1 & University of Manchester & 60 & $2.17 \%$ \\
2 & University of California System & 57 & $2.06 \%$ \\
3 & University of London & 50 & $1.80 \%$ \\
4 & University System of Georgia & 48 & $1.73 \%$ \\
5 & Tilburg University & 39 & $1.41 \%$ \\
6 & Ku Leuven & 38 & $1.37 \%$ \\
7 & Maastricht University & 38 & $1.37 \%$ \\
8 & Eindhoven University of Technology & 37 & $1.34 \%$ \\
9 & Erasmus University Rotterdam & 37 & $1.34 \%$ \\
10 & Imperial College London & 35 & $1.26 \%$ \\
11 & Bocconi University & 34 & $1.23 \%$ \\
12 & Georgia Institute of Technology & 34 & $1.23 \%$ \\
13 & Pennsylvania Commonwealth System of Higher Education Pcshe & 32 & $1.16 \%$ \\
14 & Aalto University & Copenhagen Business School & 31 \\
\hline
\end{tabular}




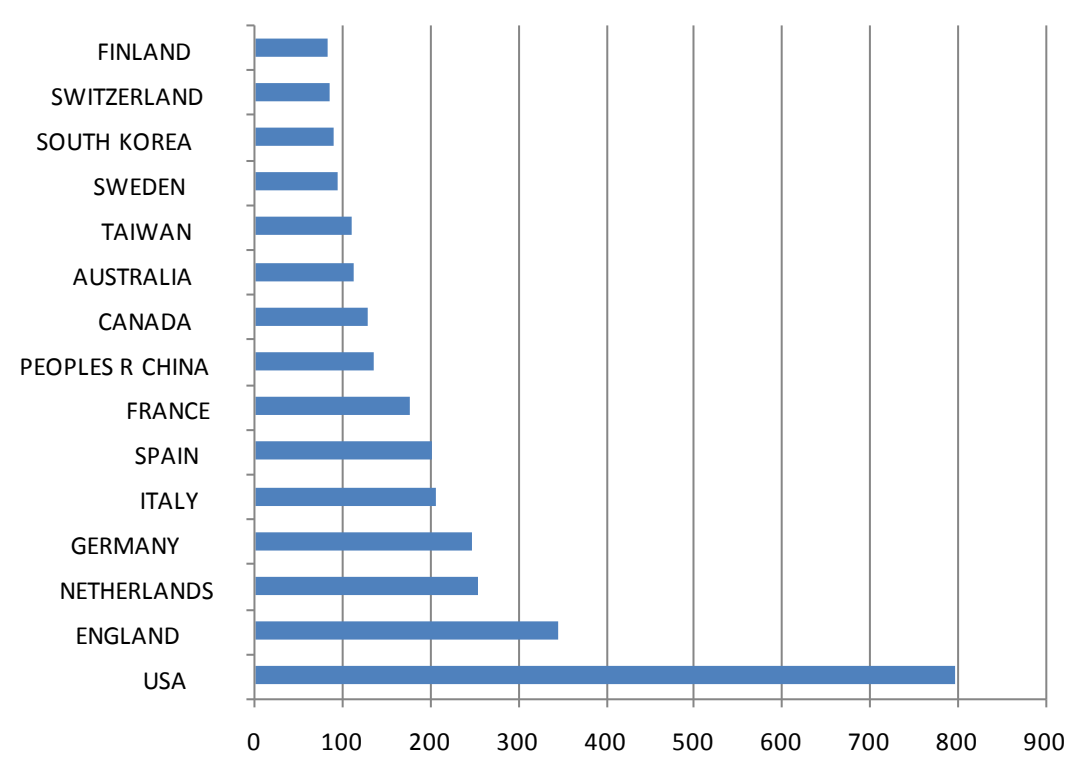

Figure 1. Distribution of countries \& areas making cooperation innovation research.

164, 179, 213, 231, 244, 306, 352, 512, 623, 667, 875, 1062, 1089 and 1280. The correlation of number of edge and key words, as shown in Figure 2, the tendency of number of nodes conforms to that of edges of network for corporation research keywords in 15 years. The cooperation innovation subjects are increasing and their correlation are much tighter.

\subsection{Stage Property of Information Network}

The paper divides the research period to several stages. The division can make the change of co-word network obvious, which facilitates the research of cooperation innovation hot spot evolution. As statistical analysis result showing, the average distance between clustering coefficient and nodes does not change much. By calculation, the average distance of them. The author divides the research period into 3 years, so there are totally five stages: 2000-2002, 2003-2005, 2006-2008, 2009-2011 and 2012-2014.

The analysis of properties of key-word network in five stages is shown in Table 6. The paper completely analyzes every criterion.

\subsection{Evolution and Visualization Analysis of Cooperative Innovation Knowledge}

In order to avoid interference, and clearly understand the cooperative innovation between the various stages of the research focus, this paper omitted the keyword such as "Innovation", "Cooperation”, "Collaboration”, "Synergy", "Partnership" and the name of national and regional. The next stage of each row in the top 50 keywords is extracted, formed co-word network, and visualization. Some in the five stages of the high frequency words is the same; each stage will have new vocabulary words, the similarities and differences of these key words as shown in Table 7.

Co-word matrix represents the co-citation data between words. Co-citation network is a one with nodes and links to visually represent the structure and relationship of keywords. In visibility graph, every node represents a key word. The size of node shows the degree centrality and the position of key word in social network. The thickness of link between nodes represents the number of co-incitation and the strength of words' relationship.

The paper reviews the co-word matrix and top cited cooperation innovation articles in every stage to cognize more about hot spots of cooperation innovation in each stage.

\subsubsection{Network Mapping of 2000-2002}

The co-word network at first stage is shown in Figure 3. The key words at the core of co-word network include Networks, Strategic Alliances, Social Network and Networks. The tightly linked words to Networks are: Strategy, regional innovation system, knowledge, development, complexity, alliance, externality, venture capital, trust. 


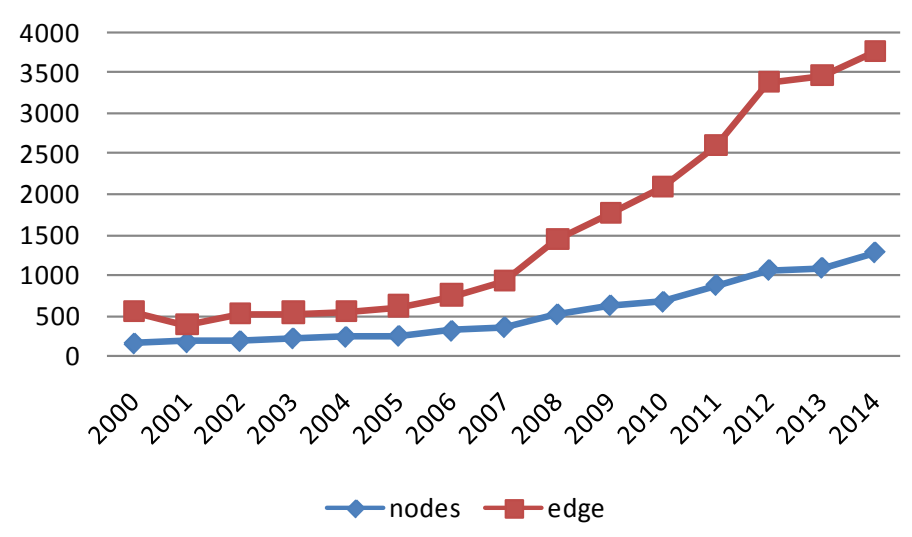

Figure 2. Curve of number of nodes and edge for co-words networks.

Table 6. The top 15 institutions of authors.

\begin{tabular}{ccccccccccc}
\hline Stage & $\begin{array}{c}\text { Number of } \\
\text { Nodes }\end{array}$ & Connect Size & $\begin{array}{c}\text { Average } \\
\text { Degree }\end{array}$ & Density & $\begin{array}{c}\text { Clustering } \\
\text { Coefficients }\end{array}$ & $\begin{array}{c}\text { Random } \\
\text { Clustering } \\
\text { Coefficients }\end{array}$ & $\begin{array}{c}\text { Average } \\
\text { Distance }\end{array}$ & $\begin{array}{c}\text { Random } \\
\text { Average } \\
\text { Distance }\end{array}$ & $\begin{array}{c}\text { Number } \\
\text { of } \\
\text { Components }\end{array}$ \\
\hline $2000-2002$ & 415 & 1187 & 5.720 & 0.0138 & 0.918 & 0.0098 & 3.938 & 3.558 & 32 \\
$2003-2005$ & 562 & 1406 & 5.004 & 0.0089 & 0.887 & 0.0067 & 4.065 & 4.072 & 40 \\
$2006-2008$ & 953 & 2645 & 5.551 & 0.0058 & 0.892 & 0.0065 & 4.170 & 4.239 & 51 \\
$2009-2011$ & 1652 & 5409 & 6.548 & 0.0039 & 0.878 & 0.0043 & 3.941 & 4.098 & 56 \\
$2012-2014$ & 2320 & 7983 & 6.882 & 0.0029 & 0.875 & 0.0030 & 3.814 & 4.217 & 52 \\
\hline
\end{tabular}

Table 7. Common keywords in five stages and new keywords in each stage.

Common keywords Strategic Alliances, Social Networks, R\&D Cooperation , R\&D, Technology Transfer, Alliances, Knowledge in five stage Management, Social Capital, Entrepreneurship, Trust, Biotechnology

Stage New Keywords in Each Stage

Networks, Policy, Technology, Electronics Industry, High Technology, Manufacturing, Regional Innovation Systems, Technology Management, Competitiveness, Environment, Knowledge, Organizational Capabilities, Supply Chain

Management, Technological Innovation, Technology Policy, Biopharmaceutical Industry, Capabilities,

2000-2002 Complementary Assets, Development, Externalities, Innovation Network, Knowledge Sharing, Knowledge Spillovers, National Innovation Systems, Venture Capital, Industrial Districts, Industry-University Collaboration, New Product Development, Performance, Research Collaboration, Research Joint Ventures, Science And Technology, Innovation System

Learning, Innovation Policy, Organizational Learning, Spillovers, Appropriability, Organization, Diffusion, Project 2003-2005 Management, Regional Development, Transaction Costs, Knowledge Networks, Partnership, Contract, Outsourcing, Regional Policies, SMES, Synchronisation, Telecommunications, Automobile Industry, Clusters, Continuous Product Innovation, Patent, Product Innovation, Regional Innovation Systems, Projects

Intellectual Property Rights, Regions, Commercialization, Integration, Embeddedness, Radical Innovation,

2006-2008 Knowledge Flows, Nanotechnology, Technology Change, Teece, Exploration, Triple Helix, Knowledge Intensive Business Services, Resource-Based View

Open Innovation, Dynamic Capabilities, Inter-Firm Collaboration, Multinational Corporations (MNCs), Structural Equation Modelling, Universities, Co-Opetition, Partnerships, Process Innovation, Inter-Organizational Relationships, Knowledge Creation

2012-2014 Governance, Proximity, Firm Performance, Crowd Sourcing, Alliance Portfolio, Business Model

The words related closely to Strategic Alliances are Entrepreneur, R\&D, Organization Capability, R\&D Cooperation, Complementary Assets, Technique Interruption, Technique Management and Supply Chain Management. The key words linked to Social Network are Technique conversion, Environment, Technique Innovation, Capability and World economy. The three research subjects reflect that the relationship between Alliance Cooperation and Technique Innovation is research focus of this stage. The theme as why and how the enterprises 


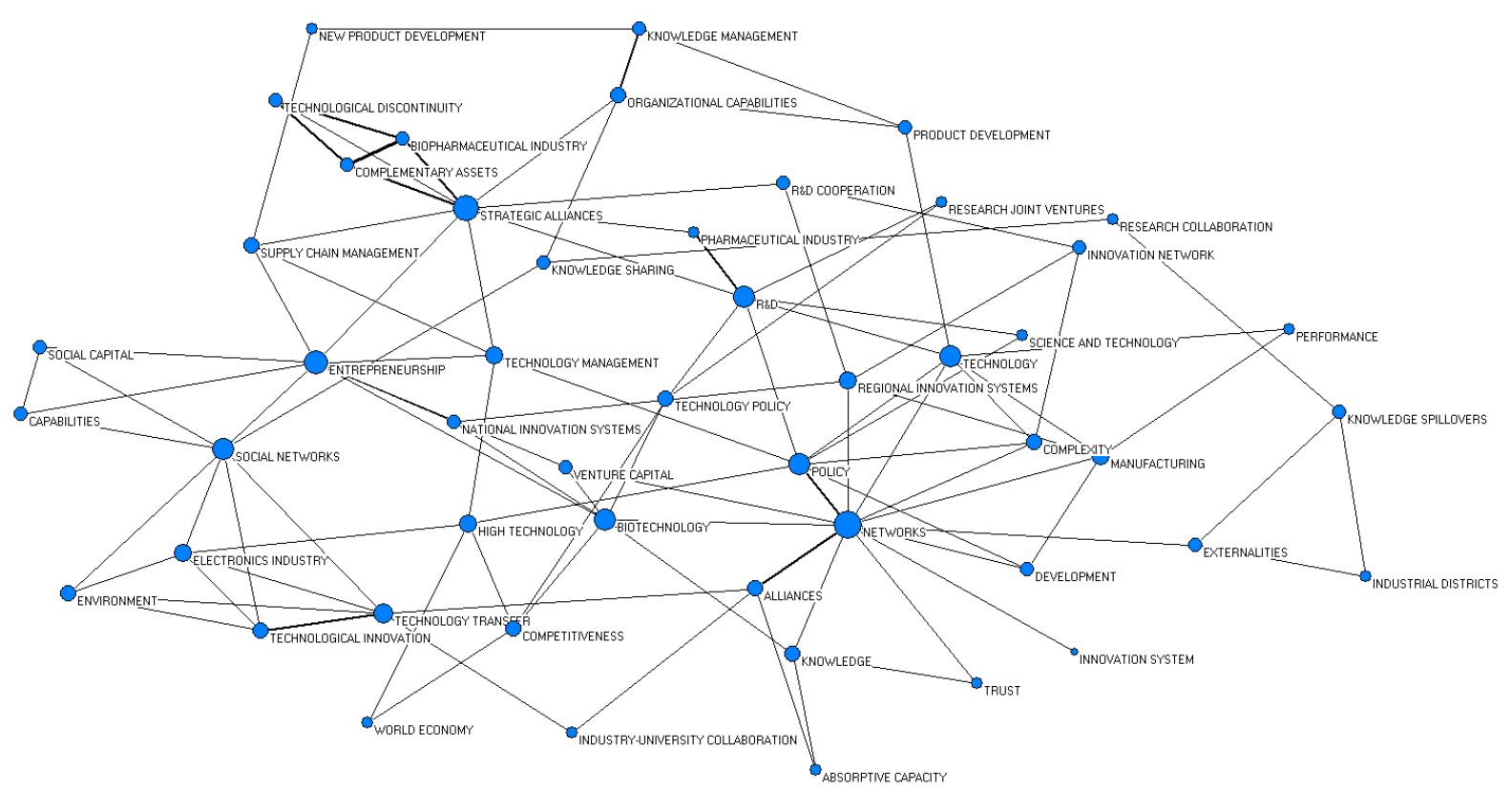

Figure 3. Network mapping of keywords co-occurrence of Cooperation Innovation Research from 2000 to 2002.

cooperate and the influence of cooperation partners like competitors, suppliers, customers, universities and research institutions on technique innovation are paid attention to in this stage. Furthermore, how the enterprise to strength the technique management and how to ensure the exclusiveness of research fruits while sharing are also the important points for the author.

\subsubsection{Network Mapping of 2003-2005}

The network mapping of co-word appeared in second stage are shown in Figure 4. The key words at the core of networks are put in descending order by degree centrality like: Biological technique, Alliance and Knowledge. In this period, scholars pay more attention to innovation activities by high-tech enterprises and how they make knowledge innovation by alliance cooperation, how the knowledge is exchanged and shared by alliance, how the knowledge affect the innovation performance, etc. The difference from the last stage lays in the tight link among core words and the role of knowledge exerted in innovation is largely affirmed.

\subsubsection{Network Mapping of 2006-2008}

The network mapping of co-word in third stage is shown as Figure 5. The key words at the core of network in descending order by centrality as Network, Knowledge, Alliances, Clusters, SMEs, Social Capital, Patents, Absorptive Capacity. In the stage, the research is not limited to binary alliance, instead, the network cooperation and innovation are also important subjects, especially how the enterprises absorb the external knowledge by forming the social network or organization network for innovation.

The co-words are not only linked tightly, but also the co-citation frequency is higher at this stage. SMEs (The small and middle-sized enterprises) were at the verge of co-word network of high-frequent words in last stage, but at the core at this stage, this shows that the cooperative innovation of small and medium enterprises become the focus of this stage in academic; furthermore, the key words like Intellectual Property, Complementary Assets, Open Innovation, Built in, Commercialization, Knowledge-Intensive Business Service, Resource-Based Theory, etc. were not high-frequent words in former two stages, but are focuses in this stage. The Exploration and Exploitation Innovation, Asset Complementary Theory, Resource Based View and Triple Helix Theory are applied in innovation theory research, making a new record for theory of cooperation innovation. New concepts and views are developed. Innovation is not only static process, but also dynamic process.

\subsubsection{Network Mapping of 2009-2011}

The network mapping of co-word in fourth stage is shown as Figure 6. Three key words: Open Innovation, Net- 


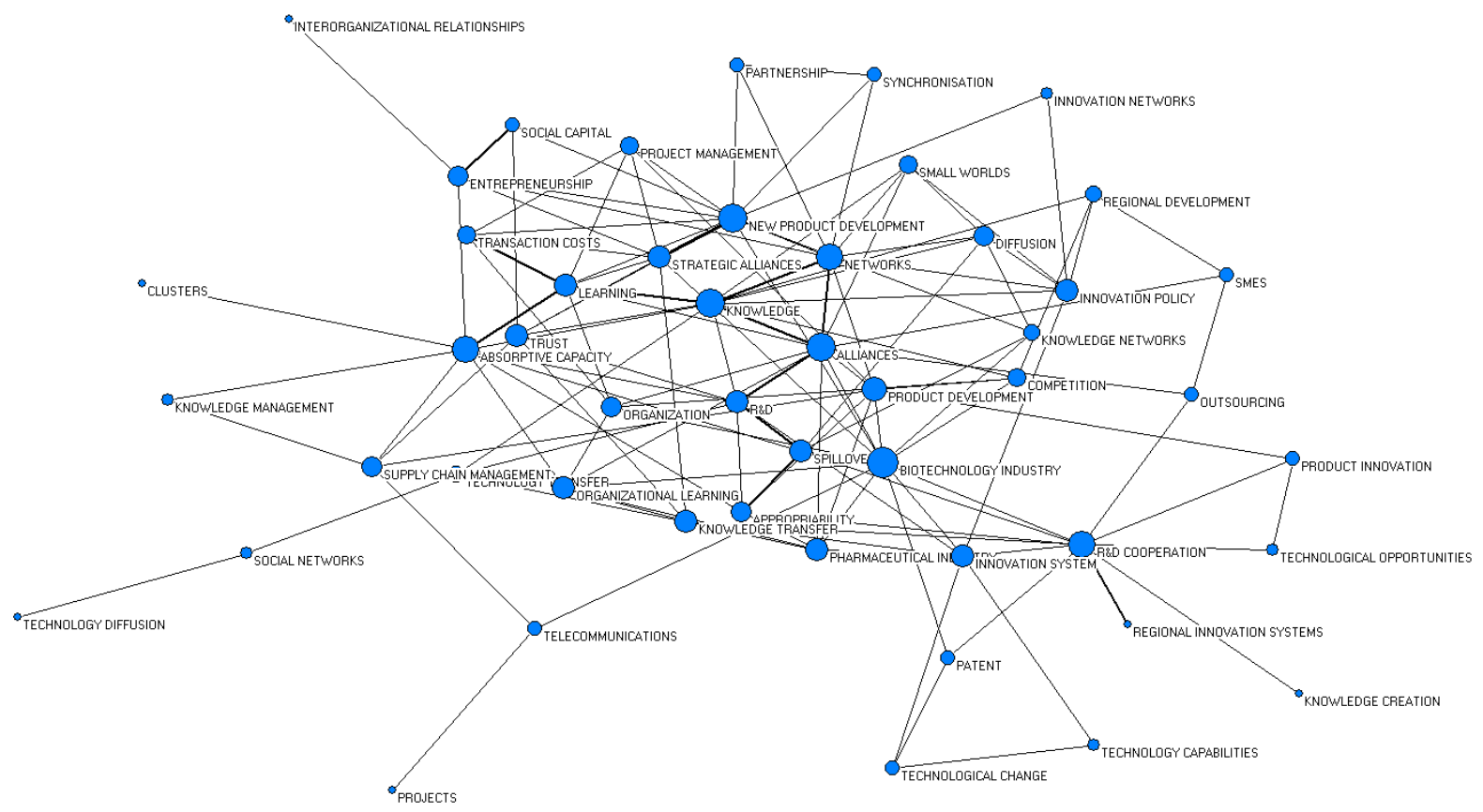

Figure 4. Network mapping of keywords co-occurrence of Cooperation Innovation Research from 2003 to 2005.

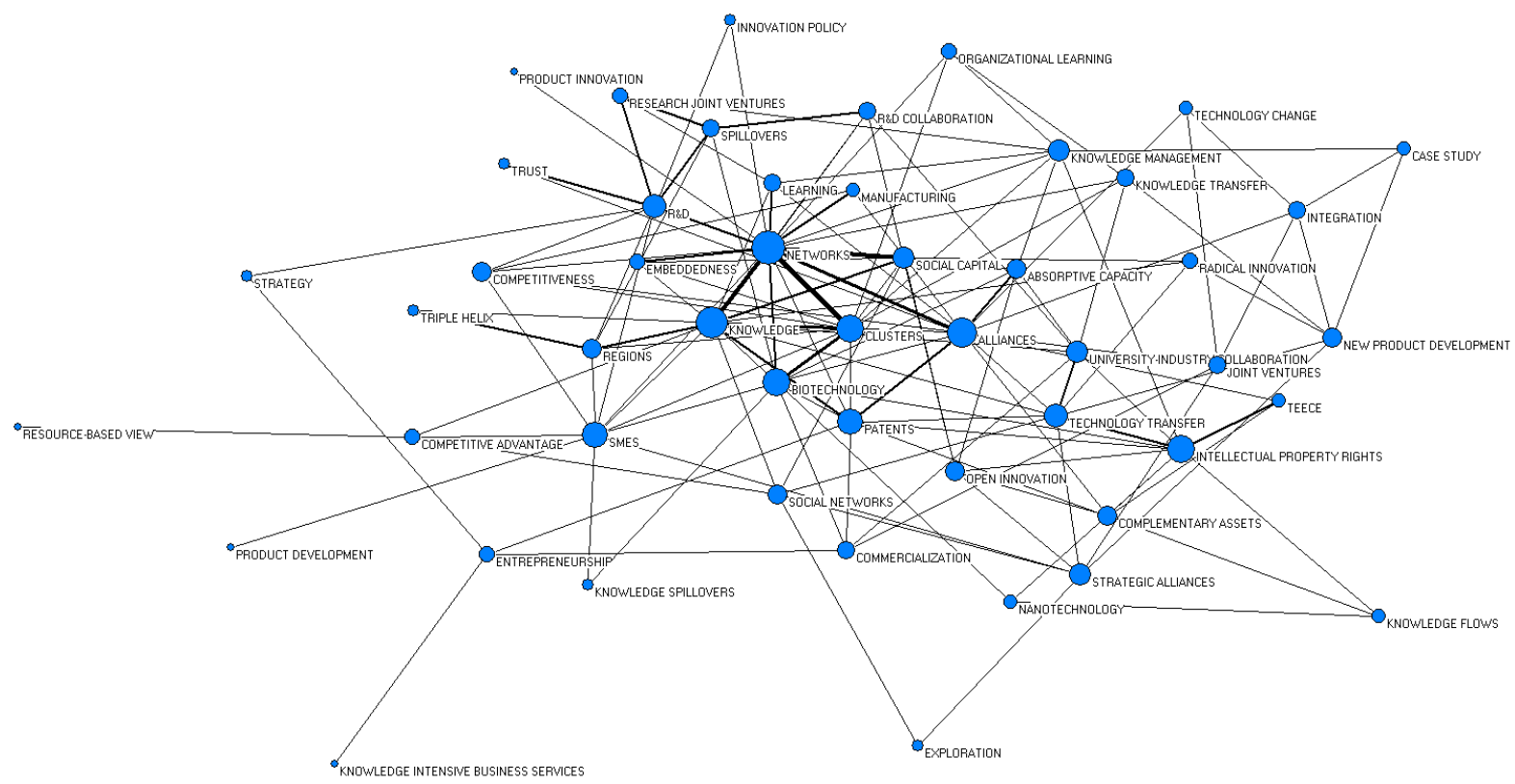

Figure 5. Network mapping of keywords co-occurrence of Cooperation Innovation Research from 2006 to 2008.

works, SMES are at core of network. The characteristic of this stage are Open Innovation is focus of research subject. Dynamic Capability, HR Management, Procedure Innovation, Cooperation Competition, Open Source Software is underscored. Besides Products Technology Innovation, Supply Chain, HR Management, this represented process of innovation management attract the attention of scholars, the process includes the internal and external integration of enterprise.

4.3.5. Network Mapping of 2012-2014

The network mapping of co-word in fifth stage is shown as Figure 7. Open Innovation, $R \& D$, SMES, Social 


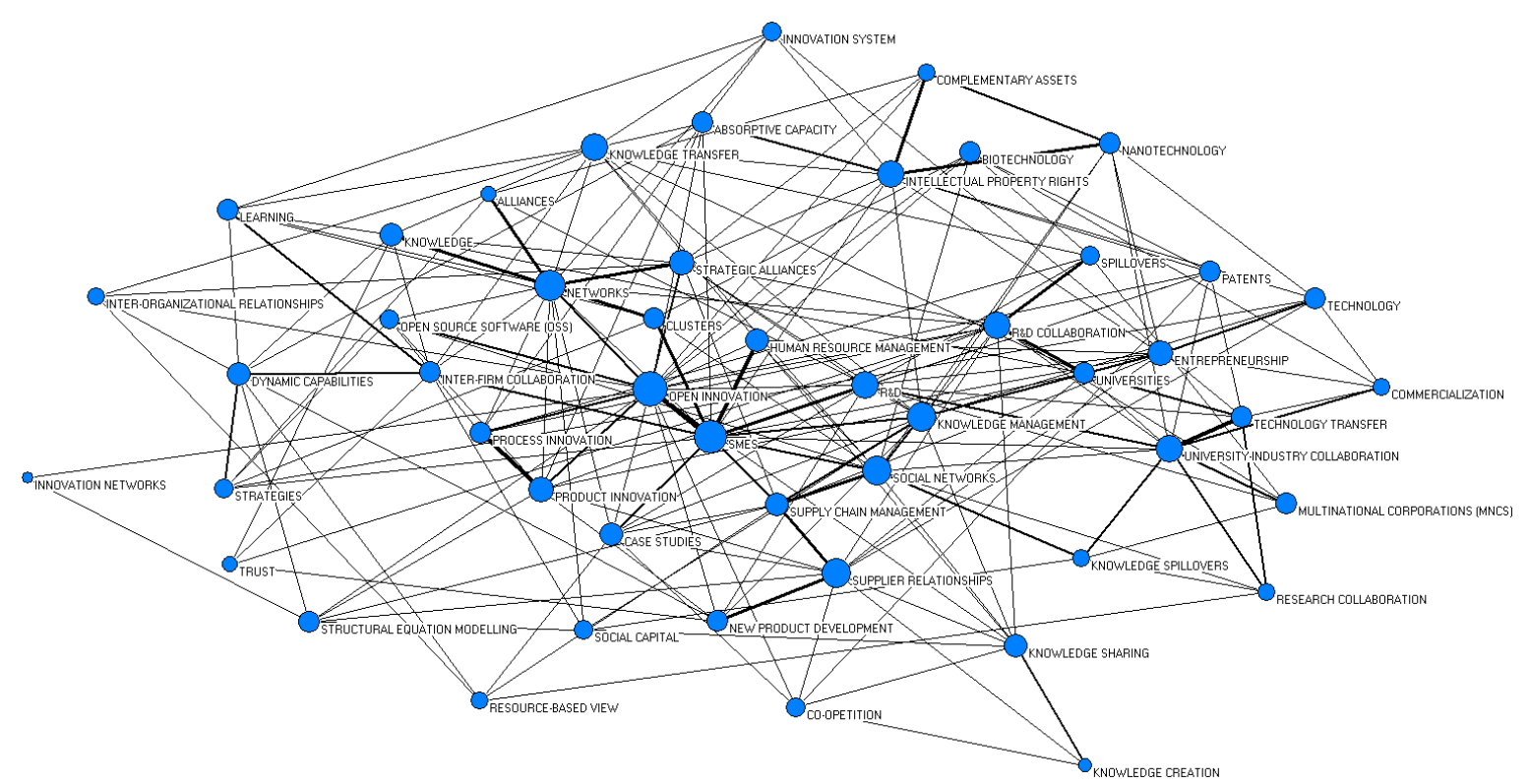

Figure 6. Network mapping of keywords co-occurrence of Cooperation Innovation Research from 2009 to 2011.

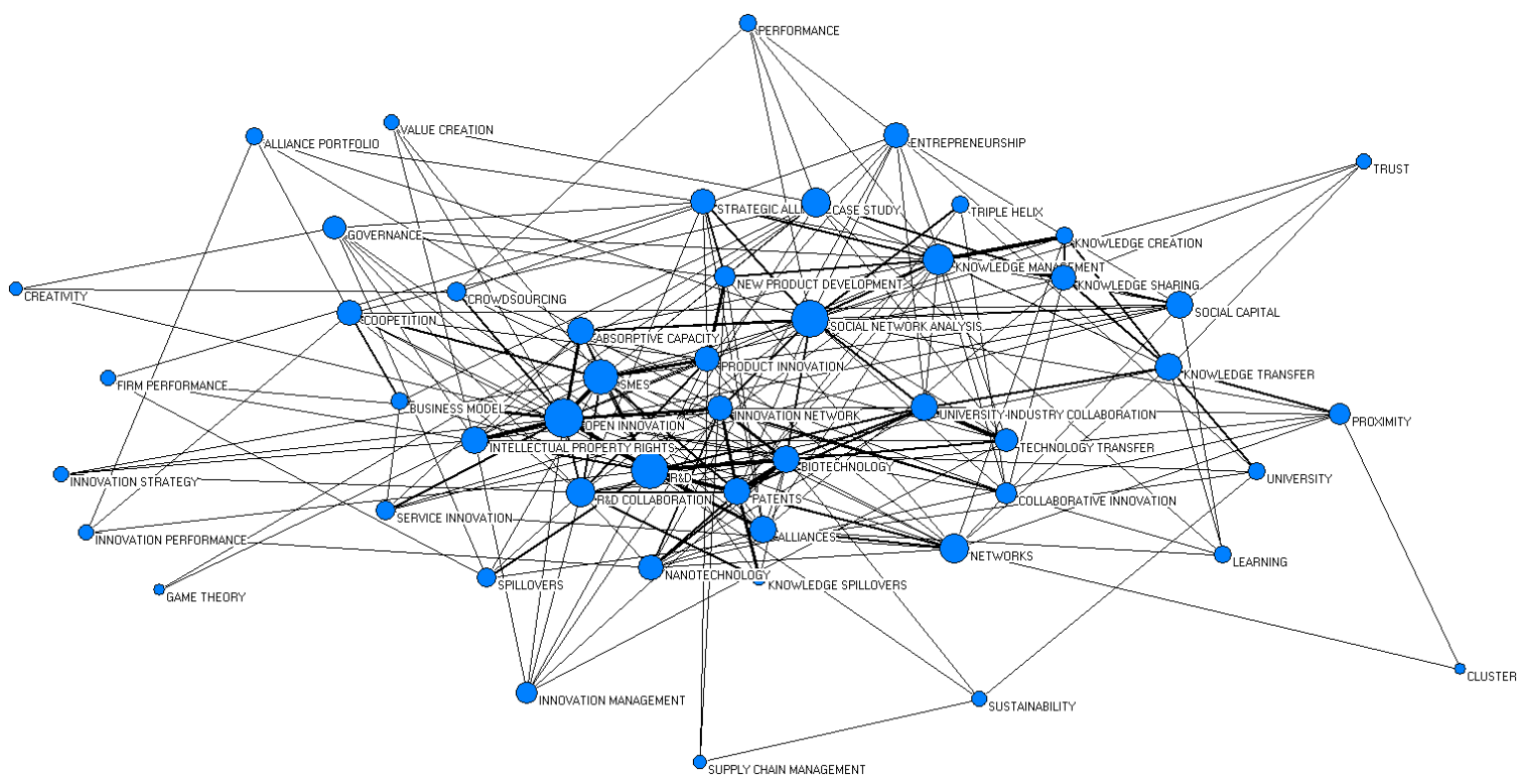

Figure 7. Network mapping of keywords co-occurrence of Cooperation Innovation Research from 2012 to 2014.

Network Analysis is at the core of network. A tight-linked condensing subgroup form, which includes 12 high frequency words: Open Innovation, R\&D, Small \& Medium-Sized Enterprises, Social Network Analysis, Knowledge Management, Network, Development Cooperation, Alliance, Social Capital, Case Study, Intellectual Property Rights, University and Industry Cooperation. The focuses are Open Innovation and Network Dynamics. The open innovation theory and its intersection and cohesion with other theories are further developed and discussed.

\section{Discuss and Conclusion}

\subsection{Conclusion}

Based on SCI articles of science and technology about cooperation innovation in economic management cate- 
gory, the paper analyzes the co-citation network of key words about cooperation innovation from 2000 to 2014. Integral knowledge structure, evolution and hot spots are explored, laying a research foundation and instruction for cooperation innovation research by economic management scholars.

Through analysis, the timetable shows the articles about innovation research are increasing from 2000 to 2014 . The discipline and perspective of periodic represent that cooperation innovation research are mainly in business economics. Distribution of organizations, countries and areas prove that the North American and European countries and universities are mainstay in cooperation innovation research; however, Asian countries like China is strengthening its research in this domain.

From 2000 to 2014, the key words about cooperation innovation research and their connection scopes are increasing. The parameters of co-word network show that the research subjects are expanding and cooperation innovation research come into a rapid development period. Co-word network matches the characteristics of smallworld network, i.e. most key words are tightly linked and subjects of cooperation innovation are closely connected.

Regarding hot spots of research, the innovation management in recent 15 years is always around eleven hot spots: Strategy Alliance, Social Network, R\&D Cooperation, R\&D, Technology Conversion, Alliance, Knowledge Management, Social Capital, Entrepreneurship, Trust and Biotechnology.

The research hot spot areas vary in different stages, but the connection of high-frequent key words are denser. Innovation management discipline represents the tendency from dispersion to fusion. Hot spots are closely related to enterprise environment at all stages. The research subject from 2000 to 2002 is Strategic Alliance and Innovation; from 2003 to 2005, Alliance and Knowledge Innovation; from 2006 to 2008, Social Network and Innovations, and from 2012 to 2014 Dynamic Network Organization and Innovation.

\subsection{Limitation}

By co-word analysis in bibliometrics and its social network tools and based on the SSCI citation index. But at the same time should not be avoided by the method, tools, macro span time, feature of subject are limited. On the one hand, econometric and statistical software itself has a certain "mechanical", the operation of the premise of co-word analysis is based on a particular threshold extracting high-frequency keywords, some less than low frequency keywords set the threshold must be excluded outside the analysis, but obviously can not underestimate the significance of research on these key words in the subject. Therefore, to reduce the threshold, number of samples of keyword extraction more co word analysis and further combined with the original documents, will more fully reveal a clear veins in the study. On the other hand, the keyword standard in articles isn't uniform, it impede to extract the co keyword precisely.

\section{References}

[1] Chesbrough, H.W. (2003) Open Innovation: The New Imperative for Creating and Profiting from Technology. Harvard Business Press, Boston.

[2] Rigby, D. and Zook, C. (2002) Open-Market Innovation. Harvard Business Review, 80, 80-93.

[3] Calantone, R.J. and Stanko, M.A. (2007) Drivers of Outsourced Innovation: An Exploratory Study. Journal of Product Innovation Management, 24, 230-241. http://dx.doi.org/10.1111/j.1540-5885.2007.00247.X

[4] Anand, B.N. and Khanna, T. (2000) Do Firms Learn to Create Value? The Case of Alliances. Strategic Management Journal, 21, 295-315. http://dx.doi.org/10.1002/(SICI)1097-0266(200003)21:3<295::AID-SMJ91>3.0.CO;2-O

[5] Gulati, R., Lavie, D. and Singh, H. (2009) The Nature of Partnering Experience and the Gains from Alliances. Strategic Management Journal, 30, 1213-1233. http://dx.doi.org/10.1002/smj.786

[6] Merchant, H. and Schendel, D. (2000) How Do International Joint Ventures Create Shareholder Value? Strategic Management Journal, 21, 723-737. http://dx.doi.org/10.1002/1097-0266(200007)21:7<723::AID-SMJ114>3.0.CO;2-H

[7] Casciaro, T. and Piskorski, M.J. (2005) Power Imbalance, Mutual Dependence, and Constraint Absorption: A Closer Look at Resource Dependence Theory. Administrative Science Quarterly, 50, 167-199.

[8] Hillman, A.J., Withers, M.C. and Collins, B.J. (2009) Resource Dependence Theory: A Review. Journal of Management, 35, 1404-1427. http://dx.doi.org/10.1177/0149206309343469

[9] Das, T.K. and Teng, B.S. (2002) The Dynamics of Alliance Conditions in the Alliance Development Process. Journal of Management Studies, 39, 725-746. http://dx.doi.org/10.1111/1467-6486.00006

[10] Zollo, M., Reuer, J.J. and Singh, H. (2002) Interorganizational Routines and Performance in Strategic Alliances. Or- 
ganization Science, 13, 701-713. http://dx.doi.org/10.1287/orsc.13.6.701.503

[11] Shan, W., Walker, G. and Kogut, B. (1994) Interfirm Cooperation and Startup Innovation in the Biotechnology Industry. Strategic Management Journal, 15, 387-394. http://dx.doi.org/10.1002/smj.4250150505

[12] Nooteboom, B. (1999) Inter-Firm Alliances: Analysis and Design. Psychology Press, London.

[13] Ahuja, G. (2000) Collaboration Networks, Structural Holes, and Innovation: A Longitudinal Study. Administrative Science Quarterly, 45, 425-455. http://dx.doi.org/10.2307/2667105

[14] Belderbos, R., Carree, M. and Lokshin, B. (2004) Cooperative R\&D and Firm Performance. Research Policy, 33, 14771492. http://dx.doi.org/10.1016/j.respol.2004.07.003

[15] Lavie, D. and Miller, S.R. (2008) Alliance Portfolio Internationalization and Firm Performance. Organization Science, 19, 623-646. http://dx.doi.org/10.1287/orsc.1070.0341

[16] Belderbos, R., Carree, M. and Lokshin, B. (2006) Complementarity in R\&D Cooperation Strategies. Review of Industrial Organization, 28, 401-426. http://dx.doi.org/10.1007/s11151-006-9102-z

[17] Hagedoorn, J., Link, A.N. and Vonortas, N.S. (2000) Research Partnerships. Research Policy, 29, 567-586. http://dx.doi.org/10.1016/S0048-7333(99)00090-6

[18] Adner, R. (2006) Match Your Innovation Strategy to Your Innovation Ecosystem. Harvard Business Review, 84, 98.

[19] Cook, K.S. (1977) Exchange and Power in Networks of Interorganizational Relations. The Sociological Quarterly, 18, 62-82. http://dx.doi.org/10.1111/j.1533-8525.1977.tb02162.x

[20] Rosenkopf, L. and Nerkar, A. (2001) Beyond Local Search: Boundary-Spanning, Exploration, and Impact in the Optical Disk Industry. Strategic Management Journal, 22, 287-306. http://dx.doi.org/10.1002/smj.160

[21] Powell, W.W., Koput, K.W. and Smith-Doerr, L. (1996) Interorganizational Collaboration and the Locus of Innovation: Networks of Learning in Biotechnology. Administrative Science Quarterly, 41, 116-145. http://dx.doi.org/10.2307/2393988

[22] Nelson, R.R. and Winter, S.G. (2009) An Evolutionary Theory of Economic Change. Harvard University Press, Cambridge.

[23] Metcalfe, J.S. (1994) Evolutionary Economics and Technology Policy. The Economic Journal, 104, 931-944. http://dx.doi.org/10.2307/2234988

[24] Levinthal, D.A. and March, J.G. (1993) The Myopia of Learning. Strategic Management Journal, 14, 95-112. http://dx.doi.org/10.1002/smj.4250141009

[25] Petruzzelli, A.M. (2011) The Impact of Technological Relatedness, Prior Ties, and Geographical Distance on University-Industry Collaborations: A Joint-Patent Analysis. Technovation, 31, 309-319. http://dx.doi.org/10.1016/j.technovation.2011.01.008

[26] Dyer, J.H. and Singh, H. (1998) The Relational View: Cooperative Strategy and Sources of Interorganizational Competitive Advantage. Academy of Management Review, 23, 660-679. http://dx.doi.org/10.2307/259056

[27] Barajas, A. and Huergo, E. (2010) International R\&D Cooperation within the EU Framework Programme: Empirical Evidence for Spanish Firms. Economics of Innovation and New Technology, 19, 87-111. http://dx.doi.org/10.1080/10438590903016492

[28] Dyer, J.H. and Hatch, N.W. (2006) Relation-Specific Capabilities and Barriers to Knowledge Transfers: Creating Advantage through Network Relationships. Strategic Management Journal, 27, 701-719. http://dx.doi.org/10.1002/smj.543

[29] Fusfeld, H.I. and Haklisch, C.S. (1985) Cooperative R-AND-D for Competitors. Harvard Business Review, 63, 60.

[30] Fritsch, M. and Lukas, R. (2001) Who Cooperates on R\&D? Research Policy, 30, 297-312. http://dx.doi.org/10.1016/S0048-7333(99)00115-8

[31] Teece, D.J. (1992) Competition, Cooperation, and Innovation: Organizational Arrangements for Regimes of Rapid Technological Progress. Journal of Economic Behavior \& Organization, 18, 1-25.

http://dx.doi.org/10.1016/0167-2681(92)90050-L 